\title{
DETERRMINAN CORPORATE SOCIAL RESPONSIBILITY (CSR) DISCLOSURE PERUSAHAAN MANUFAKTUR YANG TERDAFTAR DI BURSA EFEK INDONESIA)
}

\author{
Furqonti Ranidiah ${ }^{1}$, Geby dinasti ${ }^{2}$ \\ 12 Fakultas Ekonomi dan Bisnis UniversitasMuhammadiyah Bengkulu \\ Email: furqontiranidiah@umb.ac.id
}

\begin{abstract}
ABSTRAK
Penelitian ini bertujuan untuk mengetahui pengaruh kinerja lingkungan, komite audit, profitabilitas, Leverage, dan ukuran perusahaan terhadap pengungkapan tanggung jawab sosial perusahaan (CSR) pada perusahaan yang terdaftar di Bursa Efek Indonesia. Pengungkapan Tanggung Jawab Sosial Perusahaan diukur dengan indeks CSR berdasarkan Global Reporting Initiative (GRI) G4. Populasi penelitian ini adalah perusahaan manufaktur yang terdaftar di Bursa Efek Indonesia pada tahun 2016-2018. Data dikumpulkan dengan metode dokumentasi dan studi literatur. Pengambilan sampel menggunakan metode purposive sampling, dan diperoleh 18 perusahaan di setiap periode. Sumber data diperoleh dari laporan tahunan perusahaan yang terdaftar di Bursa Efek Indonesia di 2016-2018. Metode analisis untuk penelitian ini menggunakan analisis regresi berganda dengan SPSS 16.Hasil penelitian ini menunjukkan bahwa kinerja lingkungan dan ukuran perusahaan berpengaruh positif terhadap pengungkapan CSR. Komite audit dan profitabilitas tidak berpengaruh terhadap pengungkapan CSR, sedangkan Leverage memiliki efek negatif terhadap pengungkapan CSR.
\end{abstract}

Kata kunci: Pengungkapan Tanggung Jawab Sosial Perusahaan (CSR), kinerja lingkungan, komite audit, profitabilitas, Leverage, dan ukuran perusahaan, Global Reporting Initiative (GRI) G4

\begin{abstract}
This study aims to determine the effect of environmental performance, auditcommittee, profitability, Leverage, and company size to corporate social responsibility (CSR) disclosure in companies listed on the Indonesia Stock Exchange. Corporate Social Responsibility disclosure measured by CSR index based on the Global Reporting Initiative (GRI) G4. The population of this study are manufacturing company listed on IndonesianStock Exchange in 2016-2018. Data collected by documentation method and literature study. Sampling using purposive sampling method, and obtained 18 companies in each period. Sources of data obtained from annual reports of companies listed on Indonesia Stock Exchange in 2016-2018. The analytical method for this study uses multiple regression analysis with SPSS 16.The result of this study showed that environmental performance and company size has positiveeffect to CSR disclosure. Audit committee and profitability has not effect to CSR disclosure, while Leverage has negative effect to CSR disclosure.
\end{abstract}

Keywords: Corporate Sosial Responsibility (CSR) Disclosure, environmental performance, auditcommittee, profitability, Leverage, and company size, Global Reporting Initiative (GRI) G4. 


\section{PENDAHULUAN}

Berdirinya suatu perusahaan dapat membantu meningkatkan pertumbuhan ekonomi dan kesejahteraan sosial. Selain dianggap sebagai lembaga yang memberikan banyak keuntungan bagi masyarakat, perusahaan juga menjadi penyebab kerusakan alam di Indonesia (Makhdalena dan Trisnawati, 2016:1). Kerusakan alam di sebabkan oleh aktivitas dan kegiatan operasional perusahaan yang mengakibatkan terjadinya bencana alam, perubahan iklim, kerusakan ekosistem dan pencemaran lingkungan (Sanjaya dan Taufik, 2014:1).

Untuk mencegah kerusakan lingkungan dari aktivitas operasional perusahaan salah satu yang bias dilakukan adalah dengan menerapkan tanggung social perusahaan atau yang lebih dikenal dengan isttilah CSR. CSR merupakan inti dari etika bisnis, di mana suatu perusahaan tidak hanya mempunyai kewajibankewajiban ekonomis dan legal kepada pemegang saham (shareholders), tetapi perusahaan juga mempunyai kewajiban terhadap pihak lain yang berkepentingan (stakeholders). CSR merupakan sebuah bentuk pertanggung jawaban perusahaan kepada para stakeholders dengan memperhatikan aspek sosial dan aspek lingkungan yang ada disekitar perusahaan (Andriyani dan Abriyani 2017:1).

Alasan perusahaan dalam melakukan pengungkapan informasi CSR diantaranya adalah untuk menaati peraturan pemerintah melalui Undang-Undang No. 40 tahun 2007 tentang Perseroan Terbatas diterbitkan dan mewajibkan perseroan yang bidang usaha nya terkait dengan bidang sumber daya alam untuk melaksanakan pelaporan tanggung jawab sosial dan lingkungan. Selain itu, CSR jugadigunakanuntuk memperoleh keuntungan kompetitif, untuk memenuhi ketentuan kontrak pinjaman dan memenuhi ekspetasi masyarakat, untuk melegitimasi tindakan perusahaan, dan untuk menarik investor. CSR dipandang dapat membantu perusahaan memperbaiki kinerja keuangan dan akses pada modal, meningkatkan brand image dan penjualan, memelihara kualitas kekuatan kerja, memperbaiki pembuatan keputusan pada isu-isu kritis, mengenai resiko secara lebih efisien dan mengurangi cost jangka panjang (purnasiwi, 2011:20).

Pengambilan keputusan lainnya dapat di lihat dari kemampuan perusahaan menghasilkan laba juga dari leverage perusahaan. Gotama (2015:6) mengatakan bahwa profitabilitas merupakan faktor yang membuat manajemen menjadi bebas dan fleksibel untuk mengungkapkan pertanggungjawaban sosial kepada pemegang saham. Hubungan antara profitabilitas dan CSR adalah bahwa ketika perusahaan memiliki tingkat laba yang tinggi, perusahaan (manajemen) menganggap tidak perlu melaporkan hal-hal yang dapat menggagu informasi tentang sukses keuangan tersebut. Sebaliknya, ketika tingkat profitabilitas rendah perusahaan akan berharap pengguna laporan akan membaca laporan kinerja perusahaan. Hal ini akan mempengaruhi Nilai perusahaan Nilai perusahaan dipengaruhi oleh bebapa hal, seperti yang diungkapkan oleh (Yusmaniarti, Setiorini, \& Pitaloka, 2020) dalam penelitiannya menyatakan bahwa Leverage berpengaruh terhadap nilai perusahaan dan dan Profitabilitas tidak berpengaruh terhadap nilai perusahan. Faktor lain yang mempengaruhi CSR selain leverage dan rofitabilitasyaitu kinerja lingkungan, komite audit, ukuranp 
erusahaan. Menurut (Lako 2011:416) kinerja lingkungan yaitu kinerja perusahaan untuk ikut andil dalam melestarikan lingkungan. Perusahaan memberikan perhatian terhadap lingkungan sebagai wujud tanggung jawab dan kepedulian perusahaan terhadap lingkungan. Pada penelitian terdahulu terdapat gap yang ditemukan, dimana banyak peneliti yang menggunakan variabel yang beragam dan menampilkan hasil beragam, sehingga penelitian atas CSR perlu dilakukan lagi untuk menemukan faktor-faktor yang memang mempengaruhi CSR secara jelas, maka pengungkapan tanggung jawab sosial masih perlu diteliti lebih lanjut di Indonesia. sehingga penulis terdorong untuk melakukan penelitian mengenai Pengaruh Kinerja Lingkungan, Komite Audit,Profitabilitas, leverage, dan ukuran perusahaan Terhadap CSR Disclosure (Studi Empiris Pada Perusahaan Manufaktur Yang Terdaftar Di BEI Tahun 2016-2018). Penelitian ini bertujuan untuk mendapatkan bukti empiris mengenai kinerja lingkungan, komite audit, profitabilitas, leverage, danukuran perusahaan terhadap CSR disclosure perusahaan manufaktur yang terdaftar di Bursa Efek Indonesia.

\section{TINJAUAN LITERATUR}

\section{Teori Agensi}

Prinsip utama pada teori agensi meyatakan adanya hubungan kerja antara pihak yang memberi wewenang (prinsipal) yaitu investor dengan pihak yang menerima wewenang (agensi) yaitu manajer, dalam bentuk kontrak kerja sama yang disebut “nexus of contract” (Raharja, 2012:3). Teori agensi mengeksplorasi bagaimana kontrak dan insentif dapat ditulis untuk memotivasi individu-individu untuk mecapai keselarasan tujuan (Anthony dan Govindarajan, 2011:3). Beberapa penelitian menjadikan Teori Agensi sebagai dasar kerangka teoritis dalam keterkaitannya dengan Corporate Social Responsibility disclosure, sehingga dalam penelitian ini akan menggunakan Teori Agensi.

\section{Corporate Social Responsibility}

CSR merupakanupaya perusahaan untuk meningkatkan kepedulian terhadap masalah sosial dan lingkungan dalam kegiatan usaha dan juga pada cara perusahaan berinteraksi dengan stakeholders yang dilakukan secara sukarela. Menurut Totok M, (2014:92) Definisi CSR masih belum ada satu pun yang disetujui secara global, karena defenisi CSR dan komponen CSR dapat berbeda-beda di negara-negara atau daerah yang lain, namun umumnya CSR berbicara hubungan antara perusahaan dan stakeholders yang di dalamnya terdapat nilai-nilai pemenuhan ketentuan hukum, maupun penghargaan terhadap masyarakat dan lingkungan, serta komitmen perusahaan untuk berkontribusi dalam pembangunan berkelanjutan.

\section{Kinerja Lingkungan}

Masalah lingkungan yang ditimbulkan dari kegiatan operasi perusahaan berupa perusakan lingkungan dari perusahaan seperti yang bergerak di bidang pertambangan, mendorong munculnya praktik akuntansi lingkungan sebagai alat pertanggungjawaban atau akuntabilitas publik atas usaha yang dilakukan perusahaan Sudjoko (2011:416). Usaha pelestarian lingkungan dikenal dengan kinerja lingkungan (Wahyudi \& Busyra 
2011:416). Kinerja lingkungan adalah kinerja perusahaan untuk ikut andil dalam melestarikan lingkungan. Kinerja lingkungan dibuat dalam bentuk peringkat oleh suatu lembaga yang berkaitan dengan lingkungan hidup (Wibisono 2013:416). PROPER yang merupakan program pemeringkatan lingkungan dari Kementrian Lingkungan hidup misalnya, merupakan pemeringkatan berdasarkan kinerja lingkungan tiap-tiap perusahaan, agar bisa dibandingkan dan menjadi koreksi bagi perusahaan tersebut.

\section{Komite Audit}

Komite audit merupakan komite yang dibentuk oleh dewan komisaris yang bertugas melaksanakan pengawasan independen atas proses laporan keuangan dan audit ekstern. Keberadaan komite audit bermanfaat untuk menjamin transparansi, keterbukaan laporan keuangan, keadilan untuk semua stakeholder dan pengungkapan semua informasi yang dilakukan oleh manajemen meski ada konflik kepentingan. Sehingga, komite audit dalam perusahaan dapat menjadi salah satu upaya dalam mengurangi manipulasi dalam penyajian informasi akuntansi sehingga integritas laporan keuangan dapat meningkat(julia dkk, 2017).

\section{Profitabilitas}

Profitabilitas merupakan suatu indikator kinerja yang dilakukan manajemen dalam mengelola kekayaan perusahaan (Linda Agustina, 2012:4). Menurut Kusumadilaga (2010:333), profitabilitas merupakan kemampuan perusahaan menghasilkan laba bersih dari aktivitas yang dilakukan perusahaan pada periode akuntansi. Menurut Kamil dan Herusetya (2012:333), tingkat profitabilitas yang semakin tinggi mencerminkan kemampuan entitas dalam menghasilkan laba yang yang semakin tinggi, sehingga entitas mampu untuk meningkatkan tanggung jawab sosial, serta melakukan pengungkapan tanggung jawab sosialnya dalam laporan keuangan dengan lebih luas.

\section{Leverage}

Perusahaan dapat menggunakan hutang (leverage) untuk memperoleh modal guna mendapatkan keuntungan yang lebih tinggi. Leverage merupakan kemampuan perusahaan untuk melunasi kewajiban finansial perusahaan baik jangka pendek maupun panjang. Leverage dapat dikatakan bahwa suatu rasio keuangan yang mengukur seberapa banyak perusahaan dibiayai dengan menggunakan hutang (Wiagustini, 2010:76).Penggunaan hutang yang terlalu banyak tidak baik karena dikhawatirkan bahwa akan terjadi penurunan laba yang diperoleh perusahaan. Artinya, nilai leverage yang semakin tinggi akan menggambarkan investasi yang yang dilakukan beresiko besar, sedangkan leverage yang kecil akan menunjukkan investasi yang dilakukan beresiko kecil (Analisa, 2011:1252).

\section{Ukuran Perusahaan}

Ukuran perusahaan adalah besarnya ukuran aset yang dimilki oleh perusahaan, semakin besar ukuran perusahaan akan semakin besar pula kepercayaan investor. Perusahaan besar dianggap mempunyai kelebihan dibandingkan perusahaan kecil. Perusahaan besar mempunyai sumber daya yang besar, sehingga lebih tahan 
terhadap gejolak ekonomi dan tidak mudah bangkrut dan dapat memberikan kepercayaan yang lebih besar bagi investor (Hery, 2017:8).

\section{Kerangka Teoritik}

Kerangka pemikiran di gunakan untuk mengetahui penelitian yang sedang di bangun dalam suatu penelitian .

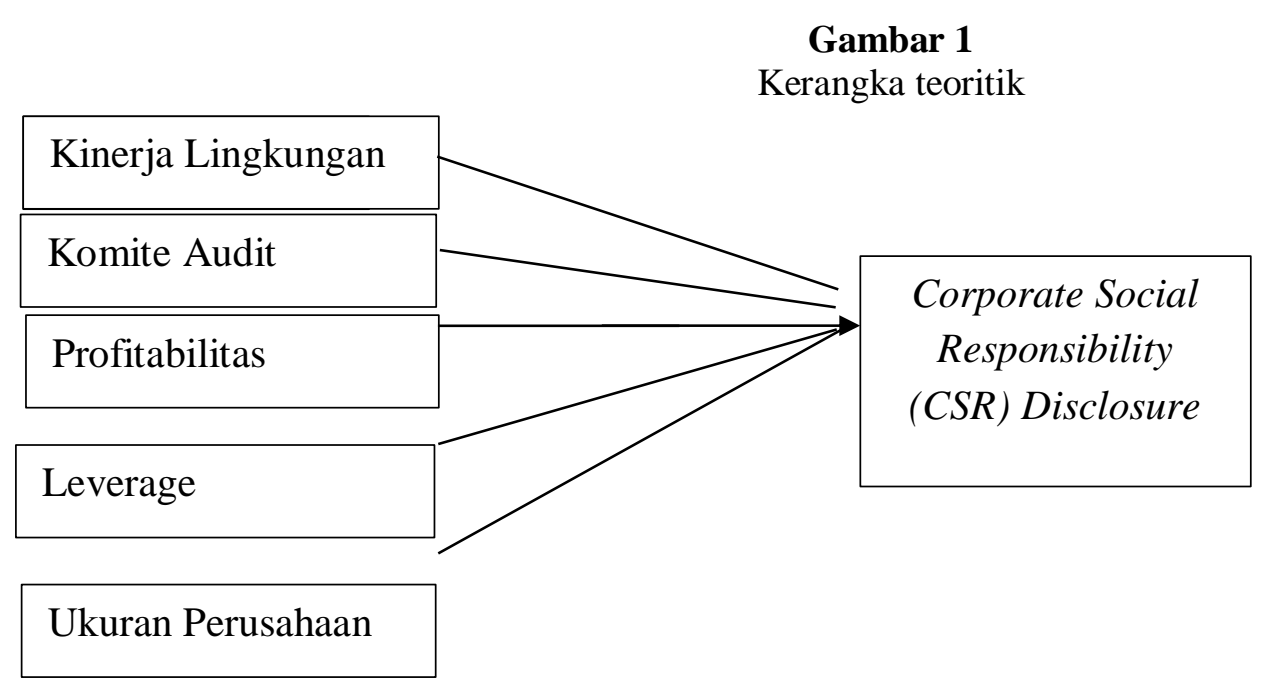

\section{METODE PENELITIAN}

Penelitian ini merupakan penelitian kuantitatif. Penelitian kuantitatif merupakan salah satu jenis penelitian yang spesifikasinya adalah sistematis, terencana, dan terstruktur dengan jelas sejak awal hingga pembuatan desain penelitiannya, dimana data yang digunakan merupakan data sekunder yang berasal dari laporan keuangan dan laporan tahunan perusahaan manufaktur yang terdaftar dalam Bursa Efek Indonesia tahun2016-2018. Sampel dalam penelitian ini menggunakan metode purposive sampling dengan keriteria sebagai berikut:

Tabel 1

Kriteria Pemilihan Sampel

\begin{tabular}{|c|c|c|}
\hline No & Kriteria & Jumlah \\
\hline 1 & $\begin{array}{l}\text { Jumlah perusahaan manufaktur yang terdaftar berturut-turut } \\
\text { di BEI pada tahun 2016-2018 }\end{array}$ & 143 \\
\hline 2 & $\begin{array}{l}\text { Jumlah perusahaan manufaktur yang tidak terdaftar berturut- } \\
\text { turut dalam PROPER tahun 2016-2018 }\end{array}$ & $(116)$ \\
\hline 3 & $\begin{array}{l}\text { Jumlah perusahaan manufaktur yang terdaftar berturut-turut } \\
\text { dalam PROPER tahun 2016-2018 }\end{array}$ & 27 \\
\hline \multirow[t]{2}{*}{4} & $\begin{array}{l}\text { perusahaan yang tidak menggunakan mata uang rupiah } \\
\text { dan perusahaan yang mengalami kerugian }\end{array}$ & (9) \\
\hline & Jumlah Sampel & 18 \\
\hline
\end{tabular}




\section{HASIL}

\section{Uji asumsi klasik}

Jumlah data dalam penelitian ini sebanyak 54 data observasi, kemudian dilakukanoutliers sehingga tersisa 48 data observasi yang bisa dianalisa lebih lanjut.

\section{Uji normalitas}

Hasil uji normalitas yang dilakukan pada penelitian ini dapat dilihat pada tabel berikut :

Tabel 2

Hasil uji normalitas

One-Sample Kolmogorov-Smirnov Test

\begin{tabular}{|ll|r|}
\hline & & $\begin{array}{c}\text { Unstandardize } \\
\text { d Residual }\end{array}$ \\
\hline $\mathrm{N}$ & Mean & 48 \\
Normal Parameters ${ }^{\mathrm{a}}$ & Std. Deviation & .0000000 \\
& Absolute & .00742406 \\
Most Extreme & Positive & .105 \\
Differences & Negative & .105 \\
& & -.057 \\
Kolmogorov-Smirnov Z & .728 \\
Asymp. Sig. (2-tailed) & & .664 \\
\hline a. Test distribution is Normal. & \\
\hline
\end{tabular}

Sumber : data sekunderdiolah, 2019

Berdasarkan hasil analisis diatas,nilai signifikansi pada uji normalitas sebesar 0,664 artinya nilai signifikansi tersebut lebih besar dari 0,05 sehingga data yang telah di uji tersebut berdistribusi normal.

\section{Uji Multikolinieritas}

Tabel 3

Hasil uji multikolinieritas

Coefficients $^{\mathrm{a}}$

\begin{tabular}{|c|c|c|c|c|c|c|c|c|}
\hline \multirow{2}{*}{\multicolumn{2}{|c|}{ Model }} & \multicolumn{2}{|c|}{$\begin{array}{l}\text { Unstandardized } \\
\text { Coefficients }\end{array}$} & \multirow{2}{*}{$\begin{array}{c}\begin{array}{c}\text { Standardized } \\
\text { Coefficients }\end{array} \\
\text { Beta }\end{array}$} & \multirow[b]{2}{*}{ 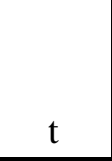 } & \multirow[b]{2}{*}{ Sig. } & \multicolumn{2}{|c|}{$\begin{array}{c}\text { Collinearity } \\
\text { Statistics }\end{array}$} \\
\hline & & B & Std. Error & & & & Tolerance & VIF \\
\hline 1 & (Constant) & -.314 & .060 & & -5.206 & .000 & & \\
\hline & KL & .013 & .006 & .213 & 2.043 & .047 & .750 & 1.33 \\
\hline & KA & -.002 & .004 & -.051 & -.537 & .594 & .893 & 1.12 \\
\hline & ROE & -.011 & .009 & -.117 & -1.207 & .234 & .865 & 1.15 \\
\hline & DER & .001 & .007 & .008 & .082 & .935 & .836 & 1.19 \\
\hline & UK & .032 & .005 & .664 & 6.411 & .000 & .761 & 1.31 \\
\hline
\end{tabular}

a. Dependent Variable:CSR

Sumber : data sekunder diolah, 2019 


\section{JAKTIA

Berdasarkan pada hasil analisis uji multikolinearitas di atas Kinerja Lingkungan, Komite Audit, Profitabilitas, Leverage, dan Ukuran Perusahaan memiliki nilai Tolerance lebih besar dari 0,10 dan memiliki nilai VIF lebih kecil dari 10 artinya variabel tersebut terbebas dari multikolinearitas atau dapat dipercaya dan obyektif.

\section{Uji Heteroskedastisitas}

Tabel 4

Hasil uji heteroskedastisitas

\begin{tabular}{|c|c|c|c|c|c|c|}
\hline \multirow{2}{*}{\multicolumn{2}{|c|}{ Model }} & \multicolumn{2}{|c|}{ Unstandardized Coefficients } & \multirow{2}{*}{$\begin{array}{c}\begin{array}{c}\text { Standardized } \\
\text { Coefficients }\end{array} \\
\text { Beta }\end{array}$} & \multirow[b]{2}{*}{$\mathrm{t}$} & \multirow[b]{2}{*}{ Sig. } \\
\hline & & B & Std. Error & & & \\
\hline \multirow[t]{6}{*}{1} & (Constant) & .057 & .026 & & 2.198 & .034 \\
\hline & KL & -.003 & .003 & -.193 & -1.249 & .218 \\
\hline & KA & .003 & .002 & .264 & 1.866 & .069 \\
\hline & ROE & -.007 & .004 & -.266 & -1.856 & .071 \\
\hline & DER & .003 & .003 & .142 & .973 & .336 \\
\hline & UK & -.003 & .002 & -.231 & -1.512 & .138 \\
\hline
\end{tabular}

a. Dependent Variable: absres

\section{Sumber : data sekunder diolah, 2019}

Berdasarkan hasil uji diatas menunjukkan nilaisignifiksidiatas nilai 0,05 Sehingga dapat disimpulkan bahwa data model regresi tidak terjadi Heterokedastisitas.

\section{Uji Autokorelasi}

Tabel 5

Hasil uji autokorelasi

\begin{tabular}{|l|r|r|r|r|r|}
\hline Model & \multicolumn{1}{|c|}{ R } & R Square & $\begin{array}{c}\text { Adjusted R } \\
\text { Square }\end{array}$ & $\begin{array}{c}\text { Std. Error of } \\
\text { the Estimate }\end{array}$ & Durbin-Watson \\
\hline 1 & $.811^{\mathrm{a}}$ & .658 & .617 & .01828 & 1.780 \\
\hline
\end{tabular}

a. Predictors: (Constant), UK, DER, KA, ROE, KL

b. Dependent Variable: CSR

\section{Sumber : data sekunder diolah, 2019}

Berdasarkan hasil analisis di atas, terdapat nilai Durbin-Watson sebesar 1,780. Dengan tabel Durbinwatson DU $<$ DW < 4-DU yaitu $1,7725<1,780<4-1,7725$. Artinya nilai Durbin-Watson sebesar 1,780tersebut berada diantara 1,7725sampai 2,2275 sehingga dapat disimpulkan bahwa model regresi tersebut tidak terjadi autokorelasi. 


\section{Analisis Regresi Berganda}

Perhitungan statistik dalam analisis regresi linier berganda yang digunakan dalam penelitian ini adalah dengan menggunakan bantuan program komputer SPSS for windows versi 16. Ringkasan hasil pengolaan data dengan menggunakan program SPSS tersebut terdapat pada tabel berikut:

Tabel 6

Hasil analisis regresi berganda

Coefficients $^{\mathrm{a}}$

\begin{tabular}{|c|c|c|c|c|c|c|}
\hline & \multirow{2}{*}{ Model } & \multicolumn{2}{|c|}{$\begin{array}{l}\text { Unstandardized } \\
\text { Coefficients }\end{array}$} & $\begin{array}{l}\text { Standardized } \\
\text { Coefficients }\end{array}$ & \multirow[b]{2}{*}{$\mathrm{t}$} & \multirow[b]{2}{*}{ Sig. } \\
\hline & & B & Std. Error & Beta & & \\
\hline \multirow[t]{6}{*}{1} & (Constant) & -.314 & .060 & & -5.206 & .000 \\
\hline & KL & .013 & .006 & .213 & 2.043 & .047 \\
\hline & KA & -.002 & .004 & -.051 & -.537 & .594 \\
\hline & ROE & -.011 & .009 & -.117 & -1.207 & .234 \\
\hline & DER & .001 & .007 & .008 & .082 & .935 \\
\hline & UK & .032 & .005 & .664 & 6.411 & .000 \\
\hline
\end{tabular}

a. Dependent Variable: CSR

Sumber : data sekunderdiolah, 2019

Dari tabel diatas dapat disusun persamaan regresi sebagai berikut:

CSR $=-0,314+0,013-0,002-0,011+0,001+0,032+\mathrm{e}$.

Uji koefisien determinasi $\left(\mathbf{R}^{2}\right)$

Tabel 7

Hasil uji koefisien determinasi $\left(\mathrm{R}^{2}\right)$

Model Summary ${ }^{\mathrm{b}}$

\begin{tabular}{|l|r|r|r|r|}
\hline Model & \multicolumn{1}{|c|}{$\mathrm{R}$} & R Square & \multicolumn{1}{c|}{$\begin{array}{c}\text { Adjusted R } \\
\text { Square }\end{array}$} & $\begin{array}{c}\text { Std. Error of } \\
\text { the Estimate }\end{array}$ \\
\hline 1 & $.811^{\mathrm{a}}$ & .658 & .617 & .01828 \\
\hline
\end{tabular}

a. Predictors: (Constant), UK, DER, KA, ROE, KL

b. Dependent Variable: CSR

Sumber : data sekunder diolah, 2019

Berdasarkan tabel diatas, Adjusted R Square menunjukan nilai 0,617. Artinya 61,7\% CSRdiscolusre dapat dijelaskan oleh variasi dari keempat variabel independen (Kinerja Lingkungan, Komite Audit, Profitabilitas, Leverage, dan Ukuran Perusahaan). Sedangkan sisanya dijelaskan oleh sebab-sebab yang lain di luar model. 


\section{Uji statistik}

Tabel 8

Hasil uji statistik t

\begin{tabular}{|c|c|c|c|c|c|c|}
\hline \multirow{2}{*}{\multicolumn{2}{|c|}{ Model }} & \multicolumn{2}{|c|}{ Unstandardized Coefficients } & \multirow{2}{*}{$\begin{array}{c}\begin{array}{c}\text { Standardized } \\
\text { Coefficients }\end{array} \\
\text { Beta }\end{array}$} & \multirow[b]{2}{*}{$\mathrm{T}$} & \multirow[b]{2}{*}{ Sig. } \\
\hline & & B & Std. Error & & & \\
\hline \multirow[t]{6}{*}{1} & (Constant) & -.314 & .060 & & -5.206 & .000 \\
\hline & KL & .013 & .006 & .213 & 2.043 & .047 \\
\hline & KA & -.002 & .004 & -.051 & -.537 & .594 \\
\hline & ROE & -.011 & .009 & -.117 & -1.207 & .234 \\
\hline & DER & .001 & .007 & .008 & .082 & .935 \\
\hline & UK & .032 & .005 & .664 & 6.411 & .000 \\
\hline
\end{tabular}

a. Dependent Variable: CSR

\section{Sumber : data sekunderdiolah, 2019}

Hasil uji statistik diatas dapat dimaknai sebagai berikut:

1. Pengujian hipotesis pertama

Kinerja lingkungan (KL) berpengaruhterhadap CSR Disclosure.

Berdasarkan perhitungan sebagaimana terlihat pada tabel diatas diperoleh nilai koefisiensebesar0,013. Hasil estimasi variabel kinerja lingkungan sebesar nilai t 2,043 dan nilai signifikansi sebesar 0,047maka nilai tersebut lebih kecil dari 0,05. Hal ini menunjukkan bahwa kinerja lingkungan berpengaruhterhadap CSR Disclosure. Hasil penelitian menunjukkan hasil yang konsisten dengan hipotesis pertama yang dibangun yaitu bahwa kinerja lingkungan berpengaruhterhadap CSR Disclosure sehingga hipotesis pertama diterima.

2. Pengujian hipotesis kedua

Komite audit (KA) tidak berpengaruhterhadap CSR Disclosure.

Berdasarkan perhitungan sebagaimana terlihat pada tabel diatas diperoleh nilaikoefisien sebesar -0,002. Hasil estimasi variabel komite audit sebesar nilai t -0,537 dan nilai signifikansi sebesar 0,594 maka nilai tersebut lebih besar dari 0,05. Hal ini menunjukkan bahwa komite audit tidak berpengaruh terhadap CSR Disclosure. Hasil penelitian menunjukkan hasil yang tidak konsisten dengan hipotesis kedua yang dibangun yaitu bahwa komite audit berpengaruh terhadap CSR Disclosure sehingga hipotesis kedua ditolak.

3. Pengujian hipotesis ketiga

Profitabilitas (ROE) tidak berpengaruh terhadap CSR Disclosure.

Berdasarkan perhitungan sebagaimana terlihat pada tabel diatas diperoleh nilai koefisiensebesar $-0,011$. Hasil estimasi variabel profitabilitas (ROE) sebesar nilai t -1,207 dan nilai signifikansi sebesar 0,234 
maka nilai tersebut lebih besar dari 0,05.Hal ini menunjukkan bahwa profitabilitas tidak berpengaruhterhadap CSR Disclosure. Hasil penelitian menunjukkan hasil yang tidak konsisten dengan hipotesis ketiga yang dibangun yaitu bahwa profitabilitas berpengaruh terhadap CSR Disclosure sehingga hipotesis ketiga ditolak.

3. Hipotesis keempat

Leverage (DER) tidakberpengsruh terhadap CSR Disclosure.

Berdasarkan perhitungan sebagaimana terlihat pada tabel diatas diperoleh nilaikoefisien sebesar 0,001 . Hasil estimasi variabel leverage (DER) sebesar nilai t 0,082 dan nilai signifikansi besar 0,935 maka nilai tersebut lebihbesardari 0,05. Hal ini menunjukkan bahwa leverage tidakberpengaruh terhadap CSR Disclosure. Hasil penelitian menunjukkan hasil yang tidakkonsisten dengan hipotesis keempat yang dibangun yaitu bahwa leverage berpengaruh terhadap CSR Disclosure sehingga hipotesis keempat ditolak.

5. Pengujian hipotesis kelima

Ukuran perusahaan (UP) berpengaruh terhadap CSR Disclosure.

Berdasarkan perhitungan sebagaimana terlihat pada tabel diatas diperoleh nilaikoefisien dengan arah positif sebesar 0,032. Hasil estimasi vaeiabel ukuran perusahaan (UP) sebesar nilai t 0,664 dan nilai signifikansi sebesar 0,000 maka nilai tersebut lebih kecil dari 0,05.Hal ini menunjukkan bahwa ukuran perusahaan berpengaruh terhadap CSR Disclosure. Hasil penelitian menunjukkan hasil yang konsisten dengan hipotesis kelima yang dibangun yaitu bahwa ukuran perusahaan berpengaruhterhadap CSR Disclosure sehingga hipotesis kelima diterima.

\section{Hasil uji statistik f}

Untuk pengujian hipotesis dilakukan Uji Regresi Simultan (Uji F). Uji F untuk menguji signifikansi sejauh mana variabel-variabel independen secara simultan yang digunakan mampu menjelaskan variabel dependen.

Tabel 9

Hasil uji statistik

\begin{tabular}{|c|c|c|c|c|c|c|}
\hline \multicolumn{2}{|c|}{ Model } & $\begin{array}{l}\text { Sum of } \\
\text { Squares }\end{array}$ & df & Mean Square & $\mathrm{F}$ & Sig. \\
\hline \multirow[t]{3}{*}{1} & Regression & .027 & 5 & .005 & 16.132 & $.000^{\mathrm{a}}$ \\
\hline & Residual & .014 & 42 & .000 & & \\
\hline & Total & .041 & 47 & & & \\
\hline
\end{tabular}

a. Predictors: (Constant), UK, DER, KA, ROE, KL

b. Dependent Variable: CSR

Sumber : data sekunderdiolah, 2019

Berdasarkan hasil uji terdapat nilai signifikasi sebesar 0,000 sehingga nilai tersebut lebih kecil dari 0,05. Artinya model bisa digunakan untuk memprediksi / pepramalan/ hipotesis. 


\section{PEMBAHASAN}

\section{Pengaruh kinerja lingkungan terhadap CSR Disclosure}

Berdasarkan hasil SPSS 16, diketahui bahwa secara persial, koefisien regresi variabel kinerja lingkungan (KL) sebesar 0,13. Setiap kenaikan kinerja lingkungan akan menaikkan CSR disclosure sebesar 0,13 atau $1,3 \%$. Nilai signifikan menunjukkan angka sebesar 0,047 yang nilainya lebih kecil daripada 0,05 itu berarti kinerja lingkungan memiliki pengaruh terhadap CSR Disclosure.

\section{Pengaruh komite audit terhadap CSR Disclosure}

Berdasarkan hasil SPSS 16, diketahui bahwa secara persial, koefisien regresi variabel komite audit (KA) sebesar -0,002. Setiap kenaikan komite audit akan menurunkanCSR disclosure sebesar -0,002 atau 0,2\%. Nilai signifikan menunjukkan angka sebesar 0,594 yang nilainya lebih besar dari pada 0,05 itu berarti komite audit tidak memiliki pengaruh terhadap CSR Disclosure.

Alasan ditolak hipotesis ini karena besarnya jumlah komite audit belum dapat menjadi mekanisme pengawasan yang efektif terhadap manajemen perusahaan. Selain itu alasan lainnya adalah pada tabelmengenail hasil analisis deskriptif, sebagian besar perusahaan sampel memiliki jumlah komite audit sebanyak 3 orang. Hal ini sejalan dengan keputusan Ketua Bapepam Nomor Kep- 29/PM/2004 yang termuat dalam peraturan Nomor IX.I.5 bahwa Komite Audit yang dimiliki oleh perusahaan minimal terdiri dari tiga orang, dimana sekurang-kurangnya 1 (satu) orang berasal dari Komisaris Independen dan 2 (dua) orang anggota lainnya berasal dari luar emiten atau perusahaan publik.

\section{Pengaruh profitabilitas terhadap CSR Disclosure}

Berdasarkan hasil SPSS 16, diketahui bahwa secara persial, koefisien regresi variabel profitabilitas bernilai sebesar -0,011. Setiap kenaikan komite audit akan menurunkanCSR disclosure sebesar -0,011 atau $1,1 \%$. Nilai signifikan menunjukkan angka sebesar 0,234 yang nilainya lebih besar daripada 0,05 itu berarti profitabilitas tidak memiliki pengaruh terhadap CSR Disclosure.

Alasan ditolaknya hipotesis ini karena profitabilitas yang rendah juga mencerminkan bahwa laba yang di peroleh perusahaan menjadi rendah. Laba yang rendah merupakan hal yang tidak terlalu baik bagi perusahaan dan para pemegang saham, sehingga perusahaan akan menampilkan kegiatan sosialnya untuk memberikan good news bagi pengguna laporannya.

\section{Pengaruh leverage terhadap CSR Disclosure}

Berdasarkan hasil SPSS 16, diketahui bahwa secara persial, koefisien regresi variabel leverage bernilai 0,001 yang berarti bahwa leverage tidak searah dengan CSR Disclosure. Setiap kenaikan leverage akan menaikkanCSR disclosure sebesar 0,001 atau 0,1\%. Nilai signifikan menunjukkan angka sebesar 0,082 yang nilainya lebih besar dari pada 0,05 . Hal ini menunjukkan bahwa leverage tidak berpengaruh terhadap CSR Disclosure. 


\section{JAMIA JURNAL AKUN}

\section{Pengaruh ukuran perusahaan terhadap CSR Disclosure}

Berdasarkan hasil SPSS 16, diketahui bahwa secara persial, koefisien regresi variabel Ukuran perusahaan bernilai sebesar 0,032. Setiap kenaikan ukuran perusahaan akan menaikkan CSR disclosure sebesar 0,032 atau 3,2\%. Nilai signifikan menunjukkan angka sebesar 0,000 yang nilainya lebih kecil daripada 0,05 itu berarti ukuran perusahaan memiliki pengaruh terhadap CSR Disclosure. Dengan demikian, dapat disimpulkan bahwa ukuran perusahaan yang kecil maka pengungkapan CSRnya juga besar dalam laporan tahunan perusahaan. Perusahaan besar dan perusahaan kecil mempunyai kewajiban untuk menjalankan tanggung jawab sosialnya. Hal ini karena berdasarkan Undang-undang No 40 Tahun 2007 setiap perseroan memiliki komitmen untuk berperan dalam tanggung jawab sosial dan lingkungan.

\section{DAFTAR PUSTAKA}

Andriyani, K, W, \& abriyani, P, (2017). "Analisis determinan corporate social responsibility (CSR) disclosure di indonesia”. jurnal.Simposium Nasional Akuntansi XX, Jember, 2017.

Anthony, R, N, \& govindarajan, v. (2011). "Sistem pengendalian manajemen edisi 12, jilid dua". tanggerang selatan : Karisma publising Grup

Lako, A,(2011). Dekonstruksi CSR \& Reformasi Paradigma Bisnis \& Akuntansi. Jakarta :Erlangga

Makhdalena, \& Trisnawati, F, (2016), "Pengaruh Komisaris Independen Dan Komite Audit Terhadap Pengungkapan Corporate Social Responsibility Perusahaan Pertambangan Di Bursa Efek IndonesiaPeriode 2012 s.d 2014".3(2), 1-11.

Sanjaya, T, Dkk, (2014). "Pengaruh Good Corporate Governance, Profitabilitas, Dan Ukuran Perusahaan Terhadap Pengungkapan Tanggung Jawab Sosial Perushaan Pada Perusahaan Real Estate Dan Property Yang Terdaftar Di Bursa Efek Indonesia(2010-2011) ". E-jurnal akuntansi, 1(1), $1-15$.

Purnasiwi, J, (2011), “Analisis Pengaruh Size, Profitabilitas Dan Leverage Terhadap Pengungkapan Csr Pada Perusahaan Yang Terdaftar Di Bursa Efek Indonesia”.jurnal akuntansi, 1 -63.

Raharja, V, A, P, (2012),"Pengaruh Kinerja Lingkungan Dan Karakteristik Perusahaan Terhadap Corporate Social Responsibility ( Csr ) Disclosure ( Studi Empiris Pada Perusahaan Manufaktur”.Jurnal

Accounting, $1(2), 1-12$.

Yusmaniarti, Y., Setiorini, H., \& Pitaloka, L. (2020). Influence PENGARUH GOOD CORPORATE GOVERNANCE, PROFITABILITAS, DAN LEVERAGE TERHADAP NILAI PERUSAHAAN PADA PERUSAHAAN PROPERTY DAN REAL ESTATE INDONESIA. Bilancia : Jurnal Ilmiah Akuntansi, 3(4), 406-418.

Wahyudi, Dkk, (2011). Corporate social responsibility: prinsip, pengaturan dan implementasi. Malang: In-Trans Publishing. 
JAMTA JURNAL AKUNTANSI, KEUANGAN DAN TEKNOLOGI

INFORMASI AKUNTANSI

https : http://jurnal.umb.ac.id/index.php/JAKTA/index

Vol 1. No 1. Juni

2020. hal. 1-12 